\title{
ОСОБЛИВОСТІ ДИСТАНЦІЙНОГО НАВЧАННЯ ІНОЗЕМНІЙ МОВІ МАЙБУТНІХ СОЦІАЛЬНИХ ПРАЦІВНИКІВ (В УМОВАХ КАРАНТИНУ 2020 РОКУ)
}

\author{
Лазаренко Л. М. \\ кандидат педагогічних наук, доцент, \\ завідувач кафедри іноземних мов \\ Приазовський державний технічний університет \\ вул. Університетська, 7, Маріуполь, Донещька область, Украӥна \\ orcid.org/0000-0002-5145-514X \\ lazarenkolarisapstu@gmail.com
}

\begin{abstract}
Ключові слова: Дистанційне навчання, сочіальні

працівники, іноземна мова, навички комунікації онлайн, критерії оцінювання знань.
\end{abstract}

Робота соціальних працівників вимагає від них сформованих умінь та навичок дистанційної роботи, тому навчання іноземної мови дистанційно якнайкраще сприяє розвитку таких умінь та навичок. Карантин 2020 та впровадження дистанційного навчання в усіх закладах України сприяло розвиткууміньтанавичокдистанційноїроботи. Устаттіописано особистий досвід автора з організації дистанційного навчання, визначено основні принципи організації такого процесу, а також його недоліки. Обгрунтовано необхідність чіткої організації та структурування навчального матеріалу, визначеність критеріїв оцінювання та підтримку постійного зворотного зв'язку як необхідні умови навчання. Зазначено, що основним недоліком впровадження дистанційного навчання у вищих навчальних закладах України в березні 2020 р. була невизначеність умов такого навчання, його термінів, тривалості та способів організації. У статті вказано основні недоліки дистанційного навчання з особистого досвіду автора: технічні проблеми, низька якість Інтернет-зв'язку, що унеможливлює якісне навчання, а також високу ресурсоємність дистанційного навчання, що потребує додаткових зусиль як від викладача, так і від студентів. Із метою з'ясування основних особливостей дистанційного навчання автором було проведено опитування серед студентів ДВНЗ ПДТУ, за результатами якого було проаналізовано особливості очікування студентів від дистанційного навчання та реальні практичні втілення. Отримані результати показали досить високі очікування студентів від дистанційного навчання та загальне негативне ставлення їх до нього через численні технічні проблеми. У статті запропоновано можливі варіанти оптимізації дистанційного навчання: забезпечення студентів умовами якісного зв'язку, визначення вимог до дистанційного навчання та чітке структурування програм та календарно-тематичного планування, чіткі критерії оцінювання знань студентів онлайн, збільшення кількості практичних годин у педагогічному навантаженні викладача на індивідуальну роботу (онлайн) зі студентами. 


\title{
PECULIARITIES OF DISTANCE TEACHING OF FOREIGN LANGUAGE TO FUTURE SOCIAL OFFICERS (UNDER THE LOCKDOWN 2020)
}

\author{
Lazarenko L. M. \\ Candidate of Pedagogical Sciences, Associate professor, \\ Head of the Department of Foreign Languages \\ Pryazovskyi State Technical University \\ Universytets 'ka str., 7, Mariupol, Donetsk region, Ukraine \\ orcid.org/0000-0002-5145-514X \\ lazarenkolarisapstu@gmail.com
}

Key words: Distance learning, social officers, foreign language, online communication skills, criteria for assessing knowledge.
The social officers' duties require for the well-shaped abilities and skills of distant communication, so teaching foreign languages via distant education promotes the development of such skills best. The 2020 lockdown and implementation of the distance education in all Ukrainian educational institutions provided for the development of the distance interaction skills. The article describes a personal experience of the author on organizing distant learning. The author defines basic principles of such process, as well as its drawbacks and ways to avoid them. The author notes the necessity of distinct organizing and structuring the educational material, defining strict criteria of grading and necessity of constant feedback as the necessary pre-requisites of such education. It has been noted that the key flaw of distant learning in Ukrainian educational institutions in March 2020 was its low information provision, with undefined terms, conditions and organizing methods for such learning. Simultaneously, the author states the main distant learning drawbacks, defined by her own experience: technical problems, low internet connection quality, which make high quality education impossible, as well as its high resources requirements, which needs extra efforts both from the student and teacher. In order to define the main peculiarities of distance learning, the author has surveyed the students of the State Higher Educational Establishment "Pryazovskyi State Technical University", and analyzed their expectations from distance learning and their practical realization. The obtained results evidence about rather high expectations of the students from the distance learning and total negative attitude to it due to numerous technical problems. The article provides with the possible solutions of the distant learning optimizing, such as: providing the students with high quality internet connection, defining the requirements to the syllabus and schedule, defining the grading criteria, prioritizing individual consultations of the tutor and recording this in the tutor's year curriculum report.
Постановка проблеми. Специфіка роботи соціальних працівників зумовлює необхідність формування комунікативних навичок як рідною, так і іноземною мовою. Дистанційна організація роботи соціальних працівників вважається високоефективним способом економії часу та грошей працедавця. Звідси, навчання соціальних працівників за дистанційними технологіями сприятиме формуванню навичок працювати дистанційно 3 клієнтами. Карантинні обмеження в Україні 3 березня 2020 р. зумовили необхідність запровадження дистанційного навчання в закладах вищої освіти, що стосується і майбутніх соціальних пра- цівників. Запровадження дистанційного навчання було неочікуваним, i, як наразі можна констатувати, більшість закладів вищої освіти виявилися недостатньо до нього підготовленими. Організація дистанційного навчання здійснювалася методом спроб та помилок. Наразі варто зазначити, що організація дистанційного навчання іноземної мови в групах майбутніх соціальних працівників $\epsilon$ наближеною до реальних умов майбутньої роботи останніх, як різновид ділової гри. Саме тому надзвичайно важливо дослідити та визначити особливості організації дистанційного навчання при викладанні англійської мови студентам будь-якої 
спеціальності, зокрема-соціально спрямованої. До того ж, у зв'язку 3 невизначеністю термінів карантину та загальною епідеміологічною ситуацією, ефективна організація дистанційного навчання є вельми актуальною.

Аналіз досліджень. Проблема актуальності забезпечення якісної освіти соціальних працівників досліджувалося численними українськими та зарубіжними науковцями [2; 9]. Якісна професійна підготовка у закладі вищої освіти зумовлює високу конкурентоспроможність та альтруїстичне ставлення фахівців до роботи [4]. Порівняльна характеристика особливостей підготовки соціальних працівників у Польщі [5], Канаді [6], Австрії [8], Німеччині [10] вказує на необхідність опанування соціальними працівниками іноземної мови, а також активного розвитку комунікативних навичок як рідною, так і іноземною мовою, спрямованих на взаємодію та спілкування із клієнтами. Мовний бар'єр як фактор-перешкода в роботі соціальних працівників може негативно впливати на взаємодію при здійсненні професійної діяльності [3]. Опанування комп'ютерних технологій та дистанційна робота завжди були пріоритетами для соціальних працівників [7], проте карантинні обмеження 2020 р. та впровадження дистанційного навчання та дистанційної роботи актуалізували це питання. Карантин 2020 р. актуалізував необхідність опанування дистанційних технологій [1], особливо для соціальних працівників [11]. Наразі спостерігаємо стрімке зростання досліджень та публікацій результатів досліджень, присвячених онлайн-навчанню в умовах карантину, а також дистанційній організації роботи спеціалістами всіх галузей, в тому числі соціальних працівників. Проте зарубіжні автори вже давно вивчають це питання [12], особливо зважаючи на характер роботи соціальних працівників [13]. I якщо в 2016 р. навички організації дистанційної роботи та дистанційного навчання для будь-якої спеціальності вважалися пріоритетом, проте не розглядались як необхідні [7], то в 2020 р. автори вважають опанування ними першочерговим завданням [1]. Зважаючи на те, що питання дистанційного навчання набуло актуальності з березня 2020 р., без сумніву, воно потребує подальшого опрацювання, зокрема щодо визначення недоліків та їх усунення.

Мета статті - визначити основні складові компоненти організації дистанційного навчання англійської мови майбутніх соціальних працівників, зокрема 3 урахуванням комунікативної спрямованості курсу, сформулювати основні проблеми такого навчання, визначити очікування студентів від дистанційного навчання та шляхи його оптимізації.

Виклад основного матеріалу. Дистанційне навчання - це таке навчання, яке організовано за наявності дистанції (фізичної) між учнем (студентом) та викладачем. Варто розрізняти дистанційне та онлайн-навчання, коли останнє охоплює онлайн-роботу викладача та учня (онлайн-уроки, онлайн-комунікація), тоді як дистанційне навчання (яке містить у собі в тому числі онлайн-навчання) пропонує більш широкий діапазон спільної взаємодії (робота на спеціалізованих платформах, виконання завдань тощо). Дистанційне навчання може допускати певні «живі» заняття, заліки, іспити i т.п., у той час як онлайн-навчання повністю відбувається в мережі Інтернет. Карантин 2020 р. зумовив необхідність працювати з учнями та студентами дистанційно, і численні українські педагоги 3 березня 2020 р. успішно опановують дистанційні технології, навіть у закладах, які ніколи не пропонували навчання дистанційно. 3 березня 2020 р. систематично проводились заняття 3 іноземної (англійської) мови професійного спрямування у групах майбутніх соціальних працівників. Вивчення дистанційних технологій соціальними працівниками є перспективним напрямком, оскільки такий вид роботи знадобиться для цієї спеціальності не тільки у контексті їнього навчання, але й роботи.

У II семестрі 2019-2020 н. р. автором було організовано навчання англійської мови соціальних працівників за наступною схемою: ознайомлення студентів із планом занять, визначення навантаження на кожне заняття, визначення обсягу завдань для підготовки до занять та самостійної роботи та критерії їх оцінювання, прийом виконаних завдань та їх обговорення зі студентами, а також проведення занять-зустрічей онлайн. Комунікативний характер дисципліни 3 іноземної мови зумовив необхідність проведення живих занять онлайн, проте виконання завдань та консультації онлайн зі студентами також сприяли розвитку комунікативних умінь та навичок. До кожного заняття студенти були забезпечені необхідними матеріалами (як основними, так i для додаткової підготовки), а також завданнями для самоконтролю. Визначені для кожного заняття завдання студенти надсилали викладачу на електронну пошту.

Основними складовими компонентами організації дистанційного навчання автором (викладачем) визначено таке:

1. Визначення форми проведення занять та платформи роботи; ознайомлення всіх учасників навчального процесу 3 даним пунктом. Автором було ознайомлено студентів із планом роботи, деталізовано можливість Інтернет-доступу кожного студента, визначено критерії оцінювання та вимоги до складання підсумкового контролю. Детально пояснено, на якій платформі будуть проводитися заняття та прийматися завдання 
(електронна пошта викладача, група ZOOM для проведення консультацій та занять, комунікація 3 питань організації через студентський Телеграм-канал).

2. Організаційні особливості: визначення дедлайнів для кожного завдання; ведення чіткого контролю відвідуваності та складання завдань.

3. Посилення необхідності індивідуальної роботи та проведення індивідуальних консультацій зі студентами; постійний зворотній зв'язок.

4. Під час проведення занять у ZOOM - чіткий розподіл обов'язків, поділ студентів на малі групи; під час складання діалогів чи проведення обговорення-дискусії - наголошення на правилах взаємної поваги, модерація заняття викладачем.

5. Опрацювання додаткових джерел, забезпечення студентів додатковими джерелами для самопідготовки (окрім підручників та рекомендованих джерел); робота з платформами Oxford University Press, My Grammar, You Tube.

6. Постійна корекція роботи студентів. Після кожного заняття студенти отримували тестові завдання, які викладач перевіряв та обговорював прогрес, акцентуючи увагу на основних аспектах, які потребували доопрацювання. Контрольні роботи були представлені завданнями для контролю знань граматики та лексики.

Виходячи з вищезгаданого, було зроблено такі висновки щодо особливостей дистанційного навчання англійської мови:

1) необхідно визначити та прописати чіткі критерії роботи, організації, оповіщення, оцінювання студентів. За їх відсутності спостерігається значна дезорганізація роботи;

2) дистанційне навчання є більш ресурсозатратним у порівнянні з живими заняттями, потребує більше часу на підготовку як викладача, так i студентів;

3) тривалість індивідуальної роботи та індивідуального консультування викладачем має бути збільшена принаймні вдвічі;

4) ефективність дистанційного навчання в навчанні монологічного та діалогічного мовлення є нижчою, ніж живого навчання;

5) технічне забезпечення дистанційного навчання (справна робота техніки, наявність Інтернету) має надзвичайно велике значення, на одному рівні з підготовкою викладача;

6) без постійного зворотного зв'язка між викладачем та студентом якість навчання суттєво погіршується. Недостатньо лише забезпечувати студентів завданнями і перевіряти їх; потрібно постійно обговорювати складні моменти;

7) у контексті навчання соціальних працівників дистанційне навчання є цікавим варіантом ділової гри, де відпрацьовуються навички комунікації онлайн, необхідні для їхньої подальшої роботи.
Недоліками дистанційного навчання автором було визначено таке:

1. Психологічна неготовність деяких студентів та несприйняття дистанційного навчання (багато хто вважав, що така форма навчання триватиме недовго, відтак не виконувалися завдання, студенти вчасно не складали теми).

2. Необхідність постійного контролю 3 боку викладача, відсутність самостійності та ініціативності студентів.

3. Проблеми 3 технічним забезпеченням (непрацююча камера, відсутність принтера, погана якість Інтернет-зв' язку).

4. Невміння працювати в команді (онлайн робота дуже сильно підкреслює невміння працювати в команді, живі заняття не настільки потребують, як виявилося, згуртованості та вмінь Теат work від студентів).

5. Недостатня кількість часу на індивідуальну роботу зі студентами. В середньому одному студенту на тиждень потрібно було приділити від 5 до 30 хвилин, що є значно більш ємним, ніж при роботі в аудиторії.

Із метою оптимізації дистанційного навчання на початку проведення дистанційних занять серед студентів - майбутніх соціальних працівників ДВНЗ ПДТУ було проведено опитування, під час якого були поставлені наступні запитання: «Чи очікуєте ви складнощі в дистанційному навчанні?» (відповідь: так/ ні/ не знаю), «Чи вважаєте ви, що дистанційне навчання буде ефективнішим за живе?» (відповідь: так/ ні/ однаково), «Якби ви могли обирати, чи навчалися би ви дистанційно?» (відповідь: так/ ні/ не знаю), і вільне запитання: «Які проблеми можуть виникати при дистанційному навчанні?». Було опитано 16 студентів першого курсу, 12 студентів 2-го курсу та 6 студентів 5-го курсу (студенти магістратури), всього 33 особи. Участь в опитуванні була добровільною, за отриманої згоди студентів. Були отримані наступні результати.

Щодо очікувань студентів, 3 опитаних 33 осіб 26 осіб (78.7\%) не очікували складнощів, 3 (9.09\%) студента очікували складнощі, та 4 особи (12.21\%) не визначилися. Щодо ефективності дистанційного навчання, 16 осіб (48.4\%) зазначили, що воно буде ефективнішим, 15 осіб (45.45\%) - що воно буде гіршим за живе навчання, і 2 особи (9.09\%) обрали відповідь «однаково». Щодо вибору дистанційного навчання, тільки 12 осіб (36.36\%) обрали відповідь «так, обрав би дистанційне навчання», 6 осіб (18.18\%) не визначилися, і 15 осіб (45.45\%) висловилися проти дистанційного навчання. Щодо очікувань можливих складнощів та заповнення довільної анкети, студенти найчастіше зазначали технічні проблеми та недостатню увагу з боку викладача при онлайн навчанні. 
У кінці проходження курсу перед останнім підсумковим заняттям студентам було запропоновано заповнити ту саму анкету, тільки з формулюванням «наскільки справдило дистанційне навчання ваші сподівання». Було отримано такі результати. Щодо справдження очікувань, 15 опитаних (45.45\%) не відчули складнощів, але 18 студентів $(54.55 \%)$ заявили про проблеми протягом дистанційного навчання. Щодо ефективності, 8 осіб (24.24\%) заявили про вищу ефективність дистанційного навчання порівняно з живим, 18 осіб (54.54\%) не відчули різниці, 7 студентів (21.21\%) заявили про гіршу якість дистанційного навчання. При відповіді на питання, чи обрали би вони знов дистанційне навчання, 24 особи $(72.72 \%)$ відповіли негативно і дев'ять (27.27\%) відповіли позитивно. Серед головних практичних проблем студенти зазначали технічні проблеми, відсутність Інтернет зв'язку, проблеми 3 технікою, погану якість зв'язку при спілкуванні $з$ викладачем та зменшення безпосередньої взаємодії на заняттях.

Отримані результати свідчать про те, що здебільшого недоліки дистанційного навчання не залежали від викладача. 3 іншого боку, попри досить високі очікування від дистанційного навчання, технічні проблеми та інші фактори призвели до суттєвого зниження сприйняття у студентів (26\% опитуваних, які не очікували складнощів, проти $54.55 \%$ студентів, які мали проблеми на практиці). Це призвело до ще більшого розчарування, хоча загальний рівень негативізму $(45.45 \%$ в очікуванні проти $21.21 \%$ ) зменшився після проведеного курсу. Проте кількість тих, хто після проведеного курсу обрав би дистанційне навчання, зменшилася вдвічі, що свідчить про необхідність внесення змін, зокрема забезпечення кожного студента доступом до Інтернету та доступними технічними засобами, а також збільшення нормативних годин на індивідуальні консультації в навчальному навантаженні педагогів.

Висновки. Дистанційне навчання можна визначити як спосіб організації навчання на відстані між студентом та педагогом, 3 використанням Iнтернет-технологій. Дистанційне навчання студентів майбутніх соціальних працівників - іноземній мові активно сприяє формуванню в останніх навичок та вмінь дистанційного спілкування, необхідних для професійної діяльності, відтак, носить елемент ділової гри. Основними принципами організації дистанційного навчання студентів-соціальних працівників було визначено: чіткі організаційні критеpiї, доступність інформації, забезпечення студентів технічними засобами та якісним зв'язком, постійний контроль 3 боку викладача та підтримання зворотного зв'язку, корекція результатів. Основними недоліками дистанційного навчання визначено погані технічні умови проведення занять, низьку якість зв'язку, первинну невизначеність термінів проведення дистанційного навчання, а також вищу ресурсоємність дистанційного навчання для педагогів. Проведене дослідження серед студентів майбутніх соціальних працівників в ДВНЗ ПДТУ показало, що технічні проблеми в навчанні спотворили уявлення студентів про дистанційне навчання, більше половини опитаних заявили про проблеми при навчанні, незважаючи на досить високі очікування. Вважаємо за необхідне розробити чіткі критерії проведення дистанційних занять, структурувати програму та підготувати календарно-тематичне планування саме дистанційних занять, розробити критерії оцінювання. Також вважаємо необхідним централізовано забезпечити студентам доступ до якісного Інтернет зв'язку на час проведення дистанційних занять.

\section{ЛІТЕРАТУРА}

1. Боднар Д.М. Особливості організації освітнього процесу в системі онлайн-освіти у закладах вищої освіти. Професійна компетентність учителя Нової украӥнської школи: формування, розвиток та удосконалення: матеріали Міжнародної науково-практичної інтернет-конферениії (22 травня 2020 р.). Тернопіль : ТНПУ ім. В. Гнатюка, 2020. С. 55-57.

2. Головко Н.I. Роль викладача під час професійної підготовки майбутніх працівників соціальної сфери. Соціальна робота в Україні: теорія і практика. 2013. № 1(2). С. 41-48.

3. Гришкова Р.О. Лінгвістичні та міжкультурні фактори у навчанні ділової англійської мови. Наукові записки НаУКМА: Філологічні науки. 2004. Т. 34. С. 82-84.

4. Капська А.Й. Деякі аспекти професійної підготовки соціальних педагогів і соціальних працівників. Сойіалізачія особистості: зб. наук. праиьь / за заг. ред. проф. А. Й. Капської. Т. XXVIII. Київ : НПУ, 2007. С. 3-13.

5. Когут С.Я. Системи професійної підготовки соціального педагога у вищих навчальних закладах освіти України і Польщі (порівняльний аналіз) : автореф. дис. на здобуття наук. ступеня канд. пед. наук : спец. 13.00.01 «Загальна педагогіка та історія педагогіки». Івано-Франківськ, 2005. 22 с.

6. Микитенко Н.О. Професійна підготовка соціальних працівників в університетах Канади : автореф. дис. на здобуття наук. ступеня канд. пед. наук : спец. 13.00.04 «Теорія і методика професійної освіти». Тернопіль, 2006. 20 с. 
7. Новгородський Р.Г. Інтернет-комунікації у роботі соціального працівника. Вісник Чернігівського національного педагогічного університету. Серія: Педагогічні науки. 2016. № 133. С. 160-163.

8. Павлішак О.Р. Професійна підготовка соціальних педагогів в Австрії : дис. ... канд. пед. наук: 13.00.01. Дрогобич, 2008. $221 \mathrm{c.}$

9. Петько Л.В. Стимулювання готовності майбутніх соціальних педагогів до виховної роботи у процесі вивчення іноземної мови у ВНЗ. Актуальні проблеми навчання та виховання людей з особливими потребами. 2012. № 9. С. 84-95.

10. Пришляк О.Ю. Професійна підготовка соціальних педагогів у вищих навчальних закладах Німеччини : дис. ... канд. пед. наук : 13.00.04. Тернопіль, 2009. 219 с.

11. Сидорук I. Формування соціальної компетентності майбутніх соціальних працівників засобами інформаційно комунікаційних технологій. Збірник наукових пращь Уманського державного педагогічного університету. 2020. № 1. С. 152-158.

12. Abels P. (Ed.) Distance Education in Social Work: Planning, Teaching, and Learning. New York : Springer, 2005. $184 \mathrm{p}$.

13. Gelman, C. R, Carol T. Teaching Social Workers to Harness Technology and Inter-disciplinary Collaboration for Community Service. British Journal of Social Work. 2010. № 40. Pp. 226-238.

\section{REFERENCES}

1. Bodnar, D. M. (2020), "Osoblyvosti orhanizatsii osvitnioho protsesu v systemi onlain-osvity u zakladakh vyshchoi osvity" [Peculiarities of Organizing Education within the Online System in the High School Institutions], Profesiina kompetentnist' uchytelia Novoi ukrains'koi shkoly: formuvannia, rozvytok ta udoskonalennia: materialy Mizhnarodnoi naukovo-praktychnoi internet-konferentsii 22 travnia $2020 r$. [Professional Competence of the Teacher of New Ukrainian School: Shaping, Development and Improvements. Proceedings of the International Scientific-practical Internet-conference, 22.05.2020], Ternopil : TNPU im. V. Hnatiuka, pp. 55-57 [In Ukrainian].

2. Holovko, N. I. (2013), "Rol' vykladacha pid chas profesiinoi pidhotovky maibutnikh pratsivnykiv sotsialnoi sfery" [The Teacher's Role in the Professional Training of the Future Social Officers], Sotsialna robota $v$ Ukraini: teoriia i praktyka, vol. 1(2), pp. 41-48 [In Ukrainian].

3. Hryshkova, R. O. (2004), "Linhvistychni ta mizhkulturni faktory u navchanni dilovoi anhliis'koi movy" [Language and Intercultural Factors in Teaching Business English], Naukovi zapysky NaUKMA: Filolohichni nauky [NaUKMA Scientific Proceedings: Philological Sciences], vol. 34, pp. 82-84 [In Ukrainian].

4. Kapska, A. Y. (2007), "Deiaki aspekty profesiinoi pidhotovky sotsial'nykh pedahohiv i sotsial'nykh pratsivnykiv" [Some Aspects of Professional Training of the Social Officers], Sotsializatsiia osobystosti: zb. nauk. prats' / za zah. red. prof. A. Y. Kaps'koi [Personality Socialization: Proceedings / ed. by Prof. A. Y. Kapska], Kyiv : NPU, vol. XXVIII, pp. 3-13 [In Ukrainian].

5. Kohut, S. Ya. (2005), "Systemy profesiinoi pidhotovky sotsial'noho pedahoha u vyshchykh navchal'nykh zakladakh osvity Ukrainy i Pol'shchi (porivnial'nyi analiz)" [Systems of Professional Training of Social Teachers in Universities of Ukraine and Poland: Comparative Analysis] : avtoref. dys. na zdobuttia nauk. stupenia kand. ped. nauk: spets. 13.00.01 «Zahal'na pedahohika ta istoriia pedahohiky» [Thesis abstract for Cand. Sc., 13.00.01 (General Pedagogics and History of Pedagogics)], Ivano-Frankivsk [In Ukrainian].

6. Mykytenko, N. O. (2006), Profesiina pidhotovka sotsial'nykh pratsivnykiv v universytetakh Kanady [Professional Training of Social Officers in Canadian Universities] : avtoref. dys. na zdobuttia nauk. stupenia kand. ped. nauk: spets. 13.00.04 «Teoriia i metodyka profesiinoi osvity» [Thesis abstract for Cand. Sc., 13.00.04 (Theory and Methods of Professional Education)], Ternopil. [In Ukrainian].

7. Novhorodskyi, R. H. (2016), "Internet-komunikatsii u roboti sotsial'noho pratsivnyka" [Internet Communications within the Social Officer Activity], Visnyk Chernihivs'koho natsional'noho pedahohichnoho universytetu. Seriia: Pedahohichni nauky [Bulletin of Chernihiv National Pedagogical University, Pedagogical Sciences Series], vol. 133, pp. 160-163 [In Ukrainian].

8. Pavlishak, O. R. (2008) Profesiina pidhotovka sotsial'nykh pedahohiv v Avstrii [Professional Training of Social Officers in Austria] : dys. ... kand. ped. nauk : 13.00.01 [PhD Thesis Manuscript, 13.00.01], Drohobych [In Ukrainian].

9. Petko L. V. (2012), "Stymuliuvannia hotovnosti maibutnikh sotsial'nykh pedahohiv do vykhovnoi roboty u protsesi vyvchennia inozemnoi movy u VNZ" [Stimulating Readiness of Social Officers to Moral Valueshaping Activities at Foreign Classes in Universities], Aktual 'ni problemy navchannia ta vykhovannia liudei $z$ osoblyvymy potrebamy [Actual Problems of Teaching Students with Special Needs], vol 9, pp. 84-95 [In Ukrainian]. 
10. Pryshliak, O. Yu. (2009), Profesiina pidhotovka sotsial'nykh pedahohiv u vyshchykh navchal'nykh zakladakh Nimechchyny [Professional Training of Social Teachers in the Germany Universities] : dys. ... kand. ped. nauk : 13.00.04. [PhD Thesis Manuscript], Ternopil [In Ukrainian].

11. Sydoruk, I. (2020), "Formuvannia sotsial'noi kompetentnosti maibutnikh sotsial'nykh pratsivnykiv zasobamy informatsiino-komunikatsiinykh tekhnolohii" [Shaping the Social Competence in Future Social Officers by the Informational Technoogies], Zbirnyk naukovykh prats' Umans 'koho derzhavnoho pedahohichnoho universytetu [Proceedings of the Uman State Pedagogical University], vol. 1, pp. 152-158 [In Ukrainian].

12. Abels, P. (2005), Distance Education in Social Work: Planning, Teaching, and Learning, New York : Springer.

13. Gelman, C. R, and Carol T. (2010), "Teaching Social Workers to Harness Technology and Inter-disciplinary Collaboration for Community Service”, British Journal of Social Work, vol. 40, pp. 226-238. 